\title{
A pilot case study of open innovation in a Brazilian company*
}

\author{
Paulo Augusto Cauchick Miguel ${ }^{a}$, Marly Monteiro de Carvalhob, Ana Paula Lopes ${ }^{b}$ \\ "Federal University of Santa Catarina \\ University of São Paulo \\ e-mails: paulo.cauchick@ufsc.br; marly@usp.br; aplopes@hotmail.com
}

\begin{abstract}
: open innovation represents a powerful competitive aspect not only in developed countries but also in emerging economies. In this context, this paper aims at demonstrating some aspects of the introduction of an open innovation program in a company in Brazil. A unit of analysis that produces cosmetics was selected due to its practices of innovation management, which is considered as a benchmark in the country. Case-based research was used as the methodological approach. Data were collected mostly by document analysis but some questions were answered by electronic mail to construct a case description. The company performs activities related to scientific and technological as well as market knowledge. The organization applies the concept of open innovation since the 90's and has increased its activity since then. This paper describes the open innovation program and discusses aspects of drivers and success factors for external collaborations. Results show that an infra-structure for innovation in addition to the initiatives of open innovation support company performance. There are also multiple ways of collaborations such as cooperation, co-creation, co-design, services, consulting, financing, etc. Conclusively, the results have found ground to the existing literature in the subject at some extent.
\end{abstract}

Keywords: open innovation, innovation management, collaborative innovation.

\section{Introduction}

An increased pressure for innovation has led companies to seek new ways to manage and acquire knowledge. Innovation has become an essential concept nowadays, since it offers the opportunity to create truly innovative products and/or services. Aspects such as technological changes, numerous pressures for lifecycle reduction and tough global competition make innovation management an essential tool for the survival of organizations (COOPER; EDGETT; KLEINSCHMIDT, 2001).

The motivating factors for innovating vary from company to company (HENKEL, 2006) and how each one uses the knowledge gained also generates different results regarding the ability to innovate. Moreover, innovation management is a critical activity for all companies because it supports the strategic direction, guides the resources allocation, provide sustainability to business, create new capabilities and generate new knowledge, making enterprises more competitive. Relevant outputs are value added to customer and generation of higher profit margins and better company image.

One of way to contribute with that is through open innovation, a term coined by Chesbrough in 2003 .

* This article is an expanded and updated version of a paper presented at the 19th International Conference on Industrial Engineering and Operations Management IAMOT, 2013.
It represents mainly the generation of ideas and use internal and external entities, has been a topic of interest in research (CHESBROUGH; CROWTHER, 2006; DODGSON; GANN; SALTER, 2006). In this context, this paper aims at demonstrating an innovation management program in which its purposes is to foster open innovation between the company and the community. The paper describes the program and discusses aspects of drivers and success factors for external collaborations. Besides this introduction (section 1), the paper is structured as follows. Section 2 describes the research methods adopted to develop this work. Section 3 overviews open innovation by analyzing the literature in this subject. Section 4 presents the results and discussion with regard to the literature analysis. Finally, section 4 points out some conclusive points in addition to opportunities for future studies.

\section{Research methods}

The research design is divided into two parts. The first part consists of the literature analysis on open innovation, in which the results are presented in section 3. The second part comprises the empirical analysis, i.e. the analysis of the open innovation program in the studied company. Such results are then presented in section 4 . 


\subsection{Methods for literature analysis}

The research methods are by means of bibliometric analysis of publications. An analysis of publications allows identifying the profile of the journal, as well as areas related to the subject of research (PRASAD; TATA, 2005). A bibliometric study carried out by means of a citation analysis allows achieving a literature map of the most referenced authors and works.

The sample was obtained by a literature search in the database ISI Web of Science, using the topics "open innovation" or "open innovations". This search resulted in 374 papers, including articles, reviews, abstracts, news and editorial material. Only articles in peer-reviewed journals were considered, reducing the sample to 172 publications, which involved 314 authors, 27 countries and 65 journals. After reading the abstracts, 12 articles were excluded because they did not fit the subject of research, resulting in the final sample of 160 articles. The data were processed in the software Sitka (SCHILDT, 2002) and networks were designed with the help of the software UCINET (BORGATTI et al., 2002).

Some indicators of publications were also used. The first indicator was the publication per journal and year, which identified the journals that published most of these developments as well as the publications over time. The second indicator of publications was the keywords, which enabled the identification of areas related to research. Indicators of citations were also used. The first one was the citation ranking of the top five most cited papers in the period. The second indicator was the most cited papers of the sample (11 articles), including a summary of their content. An indicator of cooperation in research was also used. It considers collaboration among countries for publications of the articles analyzed, which allowed the identification of the work published individually and those who worked in partnership with others.

\subsection{Methods for empirical analysis}

For the empirical analysis, case study was adopted as the research methodological approach. Guidelines from the existing literature were taken into consideration (e.g. YIN; GRASSI, 2005; VOSS; TSIKRIKTSIS; FROHLICH, 2002). The nature of this case study was single, descriptive with no causal relationship between variables. The unit of analysis was selected based on some criteria that could improve data quality and reliability. Company profile is detailed in the next section.

The data gathered were predominantly qualitative, obtained by a number of sources of evidence. The prime data was gathered through a two-hour company presentation about the innovation program. Data were complemented by questions answered by e-mail. The prime information was a manager responsible for the open innovation program. Personal observations were considered when doing a guided visit to the company. Finally, company archival sources (general reports, specific technical reports, company presentations, etc.) were also used to triangulate data in the analysis. Qualitative data were examined by content analysis. As known, data validity is improved by applying triangulation among the various sources of evidence (e.g. field observation, interviews, company documents, etc.).

\subsection{Context - company management and innovation}

The company is a multinational Brazilian organization, present in 11 countries. It produces non-durable goods within the cosmetic industrial sector. It is a large organization according to its revenue (about US $\$ 2.5$ billion) as well as the number of employees (approximately 7,000).

The company management system started to be developed in 2007. They change from a more centralized management approach to a more integrated model. This management changing gained speed in 2009 . The system guides business management by means of three central pillars: (i) business units (BU) and regional units (RUs), which are supported by processes, the strengthening of the organizational culture, and the development of the leadership. There are 7 BUs (four in Brazil and three abroad), which group together brands and product categories, and eleven RUs. Five RUs are in Brazil: São Paulo city; country side and coast of São Paulo; South; North and Northeast; and Rio de Janeiro, Minas Gerais, and the Midwest. The remaining six are abroad: Argentina, Chile, Peru, Colombia, Mexico, and France. The BUs and RUs provides management with more autonomy and responsibility, so their decisions are more closely connected to the interests of local stakeholders, in particular direct sales people (called 'consultants') and consumers.

The company management system is based on an integrated planning methodology, from overall strategy to the definition of targets and indicators aligned with economic, social, and environmental criteria, linked to the payment of bonuses and results. There is also a project office to ensure that the actions are well implemented. It is focused on two dozen strategic projects directly connected to the growth plans for the next few years. This is approved by the board of directors and regularly monitored by senior management. The company management system is supported by 18 macro-processes.

Innovation is currently in the company strategic issues, as one of the relevant aspects for achieving sustainability. According to the innovation network director, the vision on innovation is "create a flow of experiences of well being that exceeds the expectations of our net of relationship", in order to establish an "ecosystem of innovation". There is a vice presidency (VP) of innovation with a workforce 
of about 280 employees. This innovation VP is divided into four main groups: (i) science, technology, ideas and concepts; (ii) product development; (iii) consumer segment; (iv) innovation network and management. The latter group is responsible for the program, described further ahead in this paper. Some innovation measures are also shown in the result section.

\section{Literature bibliometry on open innovation}

This section presents the results obtained by an analysis based on a bibliometry of the literature concerning open innovation.

\subsection{Indicators of publications}

The publication sample for the literature reviewed was gathered from two data bases. The string "open innovation" was searched in the titles, abstracts and keywords. The search was limited to published articles and articles in press, selected from the following major data bases: ISI Web of Science and Scopus. These data bases represent the main academic journals related to the subject and all journals with impact factor calculated in Journal Citation Report (JCR). The initial sample size was 1062; 404 articles from ISI and 658 from Scopus. The metadata were recorded and organized by using Mendeley software.

The 404 articles in the ISI Web of Science database, which were published in 137 journals, which indicate that there is a multidisciplinary area (an average of 2.9 articles per journal). The 658 articles in the Scopus database, which were published in 159 journals, which indicate that there is a multidisciplinary area (an average of 4.1 articles per journal). The intersection among ISI and Scopus databases (articles appearing in both search procedures) were 361.

The editorial scope of this relationship journal covers topics such as management, technology, economics, science, strategy, among others. The ten top journals that published more articles about open innovation are shown in Table 1 . The scope of the three journal with most number of articles were

Table 1. Top 10 Journals.

\begin{tabular}{|l|c|}
\hline \multicolumn{1}{|c|}{ Journal } & Number of Papers \\
\hline R\&D Management & 44 \\
\hline Research Technology Management & 30 \\
\hline International Journal of Technology Management & 25 \\
\hline Technovation & 23 \\
\hline Research Policy & 21 \\
\hline Technological Forecasting and Social Changing & 11 \\
\hline Technology Analysis Strategic Management & 11 \\
\hline Journal of Product Innovation Management & 10 \\
\hline California Management Review & 9 \\
\hline Creativity and Innovation Management & 8 \\
\hline Innovation Management Policy Practice & 8 \\
\hline
\end{tabular}

- R\&D Management: publishes articles for academics and managers in the areas of innovation and research and development. The works have social, economic and environmental;

- Research-Technology Management: journal related to technological innovation, focusing on research and development of new products;

- International Journal of Technology Management: aims to develop, promote, and coordinate the science and technology management addressing issues such as competitiveness, cooperation, knowledge, information technology, globalization, among others.

The first publications date from 2003. In 2008, the articles began to increase (see Figure 1). This increase was in part the increase in publications in general, but also partly by the growth of interest in open innovation issues together.

Keywords that appeared in the sample more than 12 times (20 keywords) were considered. This filter was made of citations respecting the nomination 10 to $10 \%$ of the sample suggested by the software manual Sitkis. The stronger connections with the keyword search in this study (open innovation) were:

- Knowledge: it was strongly present in the analyzed articles. Although difficult to measure the attainment of knowledge is the subject of interest to those who innovate through collaboration;

- Performance: the texts related to the goals expected in the relations of partnership. Verifies the existence of the interaction between innovation actors;

- Innovation: mainly related to processes that involve high technology. It includes search for new technologies and sharing of costs and risks;

- Product development: articles heavily indicate an interest in investing entities together in research and development. What does each entity with the knowledge acquired in the partnership which may increase or decrease its capacity to launch innovative products.

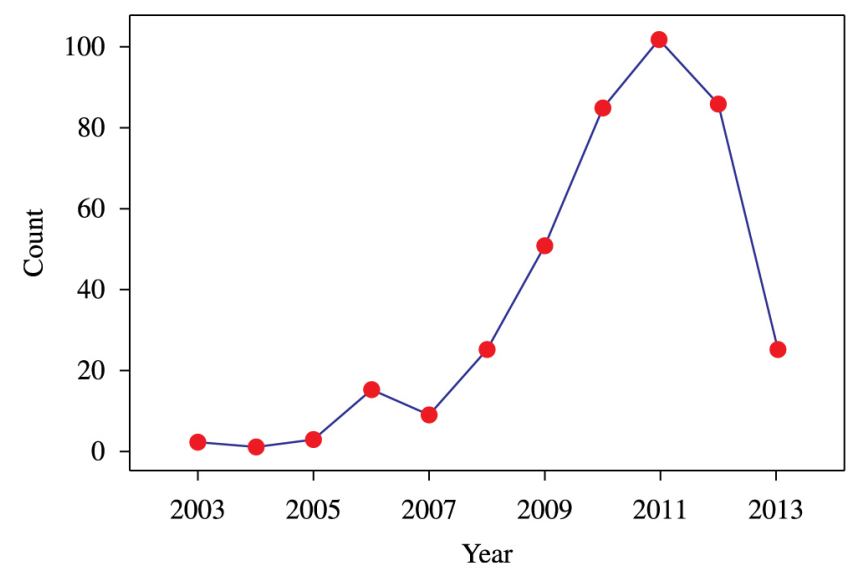

Figure 1. Number of articles published per year. 


\subsection{Indicators of citations}

Based on the total sample, the ranking of the five most cited articles from 2003 to 2013 were: Chesbrough (2003a), who introduced the concept of open innovation; Chesbrough and Crowther (2006), who identified the direct applicability of the concepts of open innovation in companies; and Henkel (2006), who identified different among the factors motivating firms to innovate. A summary of the top ten cited articles are shown in Table 2.

\subsection{Indicator of cooperation in research}

When constructing a network of collaboration for the production of the 160 articles, 6 countries have published their articles in the sample individually: Canada, France,

Table 2. Top 10 cited articles.

\begin{tabular}{|c|c|c|c|}
\hline Reference & $\begin{array}{l}\text { \# of } \\
\text { citations }\end{array}$ & Scope & Findings \\
\hline Chesbrough (2003a) & 272 & open innovation versus closed innovation & $\begin{array}{l}\text { Demonstrate applications of closed and open } \\
\text { innovation, and found that many companies } \\
\text { are in a time of transition from one to the other }\end{array}$ \\
\hline $\begin{array}{l}\text { Chesbrough and Crowther } \\
\qquad(2006)\end{array}$ & 116 & $\begin{array}{l}\text { identify companies that are not of high } \\
\text { technology and use open innovation }\end{array}$ & $\begin{array}{l}\text { Show that some concepts of open innovation, } \\
\text { such as growth in revenues and new products } \\
\text { have application in companies that are not } \\
\text { high-tech }\end{array}$ \\
\hline Henkel (2006) & 86 & Innovations that study Linux & $\begin{array}{l}\text { Find out that companies have different } \\
\text { motivations to open its innovation system, } \\
\text { which is independent of the branch in which } \\
\text { it operates }\end{array}$ \\
\hline Piller and Walcher (2006) & 80 & $\begin{array}{l}\text { explore the design and implementation of } \\
\text { "toolkits for idea competition" as a method } \\
\text { for developing new products and evaluate } \\
\text { their performance through indicators such } \\
\text { as quality of ideas generated }\end{array}$ & $\begin{array}{l}\text { Found out that the internet is an effective } \\
\text { means of integrating the user in the process of } \\
\text { developing new products, which may provide } \\
\text { a process }\end{array}$ \\
\hline $\begin{array}{l}\text { Dodgson, Gann and Salter } \\
\qquad(2006)\end{array}$ & 77 & $\begin{array}{l}\text { test the concept of open innovation at } \\
\text { Procter \& Gamble }\end{array}$ & $\begin{array}{l}\text { Show that new technologies of data mining, } \\
\text { prototyping and visual representation helps } \\
\text { innovation at Procter \& Gamble }\end{array}$ \\
\hline Cooke (2005) & 75 & $\begin{array}{l}\text { origins and nature of innovation in today's } \\
\text { society }\end{array}$ & $\begin{array}{l}\text { Identify a strong influence on the type of } \\
\text { industry in the parameters of firms }\end{array}$ \\
\hline $\begin{array}{l}\text { Christensen, Olesen and Kjaer } \\
\qquad(2005)\end{array}$ & 72 & $\begin{array}{l}\text { concept of open innovation, in a dynamic } \\
\text { industry }\end{array}$ & $\begin{array}{l}\text { Confirm the proposition that the form of } \\
\text { management of technological innovation } \\
\text { influences the company's position as to its } \\
\text { ability to innovate }\end{array}$ \\
\hline $\begin{array}{l}\text { Fleming and Waguespack } \\
\qquad(2007)\end{array}$ & 67 & $\begin{array}{l}\text { types of human and social capital to identify } \\
\text { the emergence of leaders of open innovation } \\
\text { communities }\end{array}$ & $\begin{array}{l}\text { Identify that future leaders must first make } \\
\text { strong technical contributions then integrate } \\
\text { their communities in order to mobilize } \\
\text { volunteers and avoid the ever-present danger } \\
\text { of forking and batkanization. This is enabled } \\
\text { by two correlated but distinct social positions: } \\
\text { social brokerage and boundary spanning } \\
\text { between technological areas. }\end{array}$ \\
\hline West and Gallagher (2006) & 67 & $\begin{array}{l}\text { analyze the innovation strategy of firms in } \\
\text { the software industry }\end{array}$ & $\begin{array}{l}\text { Identify three main difficulties in implementing } \\
\text { open innovation: creatively exploring internal } \\
\text { innovation, incorporating external innovation } \\
\text { in internal, external make innovation occur in } \\
\text { continuous flow }\end{array}$ \\
\hline van de Vrande et al. (2009) & 62 & $\begin{array}{l}\text { investigate if open innovation practices are } \\
\text { also applied by small- and medium-sized } \\
\text { enterprises (SMEs). }\end{array}$ & $\begin{array}{l}\text { Identify that SMEs engage in many open } \\
\text { innovation practices and pursue open } \\
\text { innovation primarily for market-related } \\
\text { motives such as meeting customer demands, } \\
\text { or keeping LIP with competitors. Their most } \\
\text { important challenges relate to organizational } \\
\text { and cultural issues as a consequence of dealing } \\
\text { with increased external contacts }\end{array}$ \\
\hline
\end{tabular}


Japan, Portugal, South Korea, and Taiwan. The USA appeared with a small connection with Wales. A larger network linking up the following eight other countries: Australia, Belgium, Denmark, England, Germany, Singapore, Spain, and Switzerland. Another country that is very central in the network is Belgium, which was related to Austria, Denmark, England, Estonia, Holland, Norway, Spain, and the USA. Having presented the analysis of the literature on open innovation, attention is turned to the results and discussion of the field research.

\section{Results and discussion}

The company was founded in the late 1960s and has shown significant growth in four decades, being one of the leaders in its area of action in the Brazilian market. The company innovation program was released in 2006 to foster innovation networks between the company and the scientific community. One of its purposes is to generate and apply knowledge obtained/transferred from institutions to the company. This enables the company to incorporate science and knowledge as a relevant aspect for the implementation of its strategies. The Product Development process, called product funnel, was revised in 2010 . The structure consists of three macro phases (devise, implement and evaluate).

The company reports to apply the concept of open innovation since the 90's and have increased its activity since 2001, when emphasized the communication with the scientific community. Actually, the program was restructured recently in two steps. Firstly, a diagnostic of open innovation activities was performed in order the company identifies "where they are". They identified a predominance of bilateral relations, limited sharing and commitment, partnerships with few opportunities of strong connections, and the necessity of tools for better interactions (idea search software, portals, etc.).

The second step was towards determining to where the open innovation activities go. With the support of an external consulting, the company developed a plan to analyze publications as well as to establish stronger ties with the partners. Mostly important, it was decided to work in the concept of network. The ideal network had to have some attributes, namely: global (i.e. without geographical limits), with multi-actors (i.e. not restricted to specific institutions), sharing values (i.e. generate different ways to create value in the network), interconnected (i.e. create opportunities for connections among the actors), multiple ways of interaction (i.e. cooperation, co-development, co-creation, etc.). To sum up, the major challenge was to create condition to connect and integrate.

The main communication platform for the relationship with the scientific community is a company site (www. naturacampus.com.br). It considers not only the conventional access through the internet but also the connectivity with the social media. The site comprises data and information about science, technology, and innovation to construct the knowledge though the network. It hosts blogs and other tools for interactive communication with researchers with the company and the remaining of the network. Events, activities, research data and case studies are available in the site. In 2011, the company promotes the site to more than 500 people. There were 4.4 thousand accesses to the site and more than 100 researchers registered in the program.

\subsection{Measures of innovation}

This section highlights some of the company results with regard to some measures of its innovation investment, launching of new products, and so on. The company is within top ten Forbes the world's most innovative companies in 2011. Table 3 shows some of the measures of innovation in the company.

\subsection{Partnership}

When data were collected, partners included 25 universities and research institutes in Brazil and abroad. Those institutions work on cooperative projects in the fronts of classical and advanced science, sustainable technologies, licensing technologies, and welfare sciences. The company network involves a total of 284 partners (in 2011): 165 companies, 62 experts, 53 ICs, and 4 research agencies. Recently, a number of partnerships were established with the National (Brazilian) Laboratory of Neuroscience as well as with the Massachusetts Institute of Technology - MIT in the USA. The company also opened a laboratory for high performance research through the technique of highthroughput screening to evaluate natural and synthetic

Table 3. Innovation measures.

\begin{tabular}{|l|c|c|c|c|c|}
\hline & $\mathbf{2 0 0 7}$ & $\mathbf{2 0 0 8}$ & $\mathbf{2 0 0 9}$ & $\mathbf{2 0 1 0}$ & $\mathbf{2 0 1 1}$ \\
\hline Investment in innovation (R\$ million) & 108.4 & 103.0 & 111.8 & 139.7 & 146.6 \\
\hline Net revenue invested in innovation (\%) & 3.4 & 2.8 & 2.6 & 2.8 & 2.7 \\
\hline Number of products launched (units) & 183 & 118 & 103 & 168 & 164 \\
\hline Innovation rate $^{\mathbf{1}} \mathbf{\%}$ & 56.8 & 67.5 & 67.6 & 65.7 & 64.8 \\
\hline
\end{tabular}

\footnotetext{
${ }^{1}$ Gross revenue arising from products launched or improved over the past 24 months divided by company gross revenue for the past 12 months.
} 
substances. This project is financed by the Brazilian Ministry of Science and Technology.

\section{Conclusions}

Concerning the literature analysis of open innovation, 160 articles were published in 55 journals in various areas. Four journals focused about $50 \%$ of the publications. The analysis of keywords showed that the work was directly related to issues such as generation and use of knowledge, increased performance, and search for technological innovation and investment in research and development for new product development. Publications appeared in 2003, but increased significantly from 2006 . Some countries have conducted their research without partnership with any other country. The countries that have jointly produced were the Belgium, the Netherlands, and the USA. A limitation of this biographic research is to use a single database. A possible bias generator is the choice of analysis of the most cited as the most representative, who can be influenced by self-citation.

Concerning the studied company a number of initiatives on open innovation have been identified. The practices in the company are well-aligned with the current literature. The strategic decision was to work as an innovation network, globally, with multi-actors, interconnected, and by sharing value among the stakeholders. There were multiple ways of collaborations such as cooperation, co-creation, co-design, services, consulting, financing, and others.

\section{Acknowledgments}

The authors would like to thank CAPES (Coordenação de Aperfeiçoamento de Pessoal de Nível Superior, a Brazilian government agency for research support) as well as CNPq (Brazilian National Council for Scientific Development) for funding this research.

\section{References}

BORGATTI, S.; EVERETT, M.; FREMAN, L. Ucinet for Windows: software for social network analysis. New York: Analytic Technologies, 2002.

CHESBROUGH, H. The era of open innovation. MIT Sloan Management Review, v. 44, n. 3, p. 35-41, 2003 a.

CHESBROUGH, H.; CROWTHER, A. K. Beyond high tech: early adopters of open innovation in other industries. R\&D Management, v. 36, n. 3, p. 229-236, 2006. http://dx.doi. org/10.1111/j.1467-9310.2006.00428.x

CHRISTENSEN, J. F.; OLESEN, M. H.; KJAER, J. S. The industrial dynamics of Open Innovation - Evidence from the transformation of consumer electronics. Research Policy, v. 34, n. 10, p. 1533-1549, 2005. http://dx.doi.org/10.1016/j. respol.2005.07.002
COOKE, P. Regionally asymmetric knowledge capabilities and open innovation exploring 'Globalization 2' - A new model of industry organization. Research Policy, v. 34, n. 8, p. 1128-1149, 2005. http://dx.doi.org/10.1016/j. respol.2004.12.005

COOPER, R.; EDGETT, S.; KLEINSCHMIDT, E. Portfolio management for new product development: results of a industry practices study. R\&D Management, v. 31, n. 4, p. 361-379, 2001. http://dx.doi.org/10.1111/14679310.00225

DODGSON, M.; GANN, D.; SALTER, A. The role of technology in the shift towards open innovation: the case of Procter \& Gamble. R\&D Management, v. 36, n. 3, p. 333-346, 2006. http://dx.doi.org/10.1111/j.14679310.2006.00429.x

FLEMING, L.; WAGUESPACK, D. M. Brokerage, boundary spanning, and leadership in open innovation communities. Organization Science, v. 18, n. 2, p. 165-180, 2007. http:// dx.doi.org/10.1287/orsc.1060.0242

HENKEL, J. Selective revealing in open innovation processes: The case of embedded Linux. Research Policy, v. 35, n. 7, p. 953-969, 2006. http://dx.doi.org/10.1016/j. respol.2006.04.010

PILLER, F. T.; WALCHER, D. Toolkits for idea competitions: a novel method to integrate users in new product development. R\&D Management, v. 36, n. 3, 307-318, 2006. http:// dx.doi.org/10.1111/j.1467-9310.2006.00432.x

PRASAD, S.; TATA, J. Publications patterns concerning the role of teams/groups in the information systems literature from 1990 to 1999. Information \& Management, v. 42, n. 8 , p. 1137-1148, 2005. http://dx.doi.org/10.1016/j. im.2005.01.003

SCHILDT, H. A. Sitkis: Software for Bibliometric Data Management and Analysis. Helsinki: Institute of Strategy and International Business, 2002.

VAN DE VRANDE, V. et al. Open innovation in SMEs: Trends, motives and management challenges. Technovation, v. 29 , n. 6-7, p. 423-437, 2009. http://dx.doi.org/10.1016/j. technovation.2008.10.001

VOSS, C.; TSIKRIKTSIS, N.; FROHLICH, M. Case research in operations management. International Journal of Operations \& Production Management, v. 22, n. 2, p. 195219, 2002. http://dx.doi.org/10.1108/01443570210414329

WEST, J.; GALLAGHER, S. Challenges of open innovation: the paradox of firm investment in open-source software. R\&D Management, v. 36, n. 3, p. 319-331, 2006. http:// dx.doi.org/10.1111/j.1467-9310.2006.00436.x

YIN, R. K.; GRASSI, D. Case Study. Porto Alegre: Bookman, 2005. In Portuguese. 